\title{
Elemental Affinities in Coals from the Southern Qinshui Basin, North China
}

\author{
Xuefeng Zhou ${ }^{1, a}$, Zheng Qiu, ${ }^{1, b}$, Xiaomeng Wang ${ }^{2, c}$ \\ ${ }^{1}$ Key Laboratory of Tectonics and Petroleum Resources, the Ministry of Education, China University \\ of Geosciences, Wuhan 430074, China \\ ${ }^{2}$ Qinghai Drilling Company, CNPC Western Drilling Corporation, Dunhuang 736202, China; \\ aydt1111@gmail.com, bzhengq99@gmail.com, wangxm@gmail.com
}

\begin{abstract}
Keywords: Coal, Geochemistry, Trace elements, Qinshui Basin
Abstract. The occurrence and distribution of major, trace and rare earth elements have been investigated in two coal-bearing units in the Qinshui Basin, northern China: the Carboniferous and Permian coals. The arithmetic means of concentrations for most elements in the Carboniferous and Permian coal samples, although in a relatively low level, is present in the range of the world concentrations. The coals in the Late Carboniferous Formation are enriched in $\mathrm{Ca}, \mathrm{Fe}, \mathrm{Mg}$ and $\mathrm{Cd}$, while the coals in the Early Permian are enriched in $\mathrm{P}, \mathrm{Ti}, \mathrm{Ba}$ and $\mathrm{Nb}$. There are no distinct differences of $\mathrm{Al}, \mathrm{Na}, \mathrm{Be}$ and other elements in these two strata. Five groups of the elements in the Carboniferous and seven groups of the elements in the Permian may be classified according to the mode of occurrence in coals. Major differences found between the Carboniferous and Permian coals are probably related to the different depositional setting, given that the Carboniferous coals were deposited on a tidal flat, and the Permian coals were accumulated in delta plain environment.
\end{abstract}

\section{Introduction}

Coal is a complex heterogeneous mixture, and its properties and characteristics depend on organic and inorganic constituents. Trace elements, usually adsorbed in inorganic fraction of coal, can have great economic, environmental, and human health impacts (Finkelman, 1993). Determination of trace elements in coal is significant both academically in developing coal-forming theories and practically in optimizing coal utilization, because these elements may serve as indicators of mineralization during coal formation and some elements are major contributors to environmental pollution during coal combustion and utilization (Dai et al., 2004). The geochemistry of coals from coalfields in Northern China have been documented by many authors (Dai et al., 2006, 2012), but little information is available from the coalfields in Shanxi Province, especially in Qinshui Basin, where coal and coalbed methane exploration are still ongoing. The purpose of this paper is to investigate the mineralogy, content, and modes of occurrence of major, trace and rare earth elements in the coals from the Zhenzhuang area, Southern Qinshui Basin.

\section{Geological setting}

The Qinshui basin is located at $35^{\circ} 15^{\prime}-38^{\circ} 10^{\prime} \mathrm{N}$ and $111^{\circ} 45^{\prime}-113^{\circ} 45^{\prime} \mathrm{E}$ (Fig. 1) in the south of Shanxi province, North China (Wei et al., 2006). It is 150-km long (N-S) and 35-km wide (W-E), with a total area of $30,000 \mathrm{~km}^{2}$. Coal reserves of the Qinshui basin amount to $300 \mathrm{Gt}$, making it one of the richest coalfields in the Shanxi province. As a Mesozoic basin evolved from the Late Paleozoic Northern China's Craton Basin, the Qinshui basin is surrounded by the uplifts of Taihang Mountain, Huo Mountain, Wutai Mountain, and Zhongtiao Mountain (Su et al., 2005) (Fig. 1). There are over 15 coal seams from Carboniferous to Permian age, including both workable and unworkable seams within the coal-bearing strata in this area. The Taiyuan and Shanxi Formations are the main coal-bearing units. The thickness of coal-bearing strata of the Taiyuan formation is in the range of 90-110 m thick, with an average of $95 \mathrm{~m}$. The sedimentary facies mainly consists of pediment alluvial plain, delta plain, and shallow lacustrine sediments. 


\section{Samples and methods}

Twenty drilling exploration coal samples from five cored boreholes in the South Qinshui Basin were sampled. All samples were collected and stored in plastic bags to ensure as little contamination and oxidation as possible (Dai et al., 2004; 2006). The collection of samples was in accordance with the Chinese Standard for Collecting Channel Samples GB482-79 (Han, 1996).

Samples for geochemistry analysis were crushed and ground to less than 200 mesh. Coal samples were acid digested following a two-step digestion method devised to retain volatile elements in solution (Querol et al., 1997; Zhuang et al., 2012). The resulting solutions were analyzed by inductively coupled plasma atomic-emission spectrometry (ICP-AES) for major and trace elements and by inductively coupled plasma mass spectrometry (ICP-MS) for trace elements. Digestion of an international reference material (SARM-19) and blanks was prepared following the same procedure to check the accuracy of the digestion and the analytical methods (Zhuang et al., 2007).

\section{Results and discussion}

\section{Concentration of elements in the Carboniferous and Permian coals}

Concentrations of major, trace and earth rare elements of the Carboniferous and Permian coal samples are shown in Fig. 1. It also contains the average concentrations of elements in Chinese, USA and World coal. As for most coal samples, $\mathrm{Al}_{2} \mathrm{O}_{3}, \mathrm{CaO}$ and $\mathrm{Fe}_{2} \mathrm{O}_{3}$ are the most abundant. Abundant aluminum suggests that the mineral component of these coal samples, especially the Permian coal samples, is rich in clay minerals (Zhuang et al., 2007), and this is consistent with the occurrence of clay minerals by the XRD analysis. High Ca content may correspond to calcite remains in coal samples (Zhuang et al., 2012). Similar with the sulfur contents, as discussed above, $\mathrm{Fe}_{2} \mathrm{O}_{3}$ and Mo are more enriched in the Late Carboniferous coals (0.04-1.75\%, avg. 0.63 and 1.00-3.34\%, avg. 2.11, respectively) with respect to the Early Permian coals (0.03-0.74\%, avg. 0.19 and $0.15-3.63 \%$, avg. 0.79 , respectively). The Late carboniferous coals have relatively higher $\mathrm{Al}_{2} \mathrm{O}_{3}$ (avg. $1.88 \%$ ), $\mathrm{CaO}$ (avg. $0.60 \%$ ), $\mathrm{K}_{2} \mathrm{O}$ (avg. $0.05 \%$ ) and $\mathrm{MgO}$ (avg. 0.10\%) contents compared with the Early Permian coals, while Ti (avg. $644.16 \mathrm{ug} / \mathrm{g}$ ) and P (avg. $107.48 \mathrm{ug} / \mathrm{g}$ ) contents in the Early Permian are higher than those from the Late Carboniferous( $392.55 \mathrm{ug} / \mathrm{g}$ and $92.03 \mathrm{ug} / \mathrm{g}$, respectively). The $\mathrm{Na}_{2} \mathrm{O}$ content is very low in these two seams, with average value of $0.04 \%$ for the Late Carboniferous coals and $0.06 \%$ for the Early Permian coals.

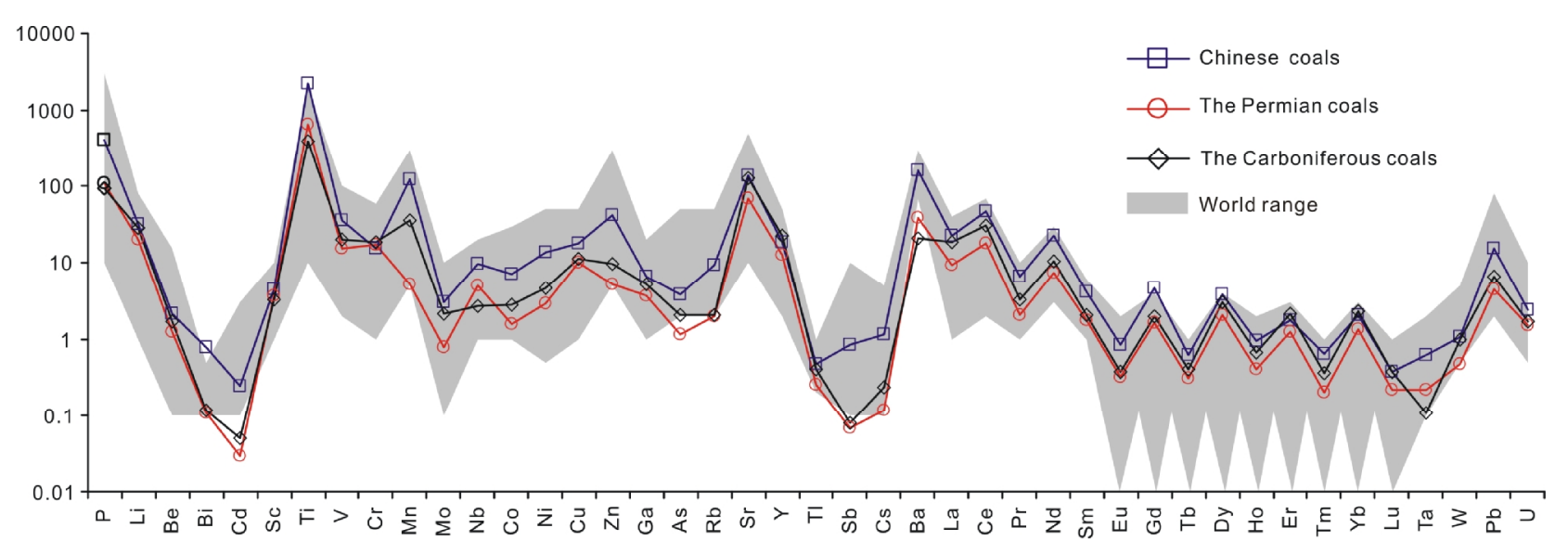

Fig. 1. Trace element concentrations of the Carboniferous and Permian coals compared with Chinese and worldwide coals. Chinese, Zhao et al. (2002) and Dai et al. (2012); World range, Swaine (1990).

Hierarchical cluster analysis data was applied to evaluate the correlation between the major elements, trace elements, and rare earth elements determined in the samples obtained from the Zhengzhuang area, Qinshui Basin. The affinity of some trace elements may vary in the Permian and Carboniferous coal seams owing to the previously described mineralogical differentiation; 
consequently, the intercorrelation treatment has been carried out separately for the Carboniferous and Permian coals .

According to the dendrogram the major, trace, and rare earth elements of coal can be grouped into five major populations (Fig. 2), of which some are characterized by the formation of several sub-populations.
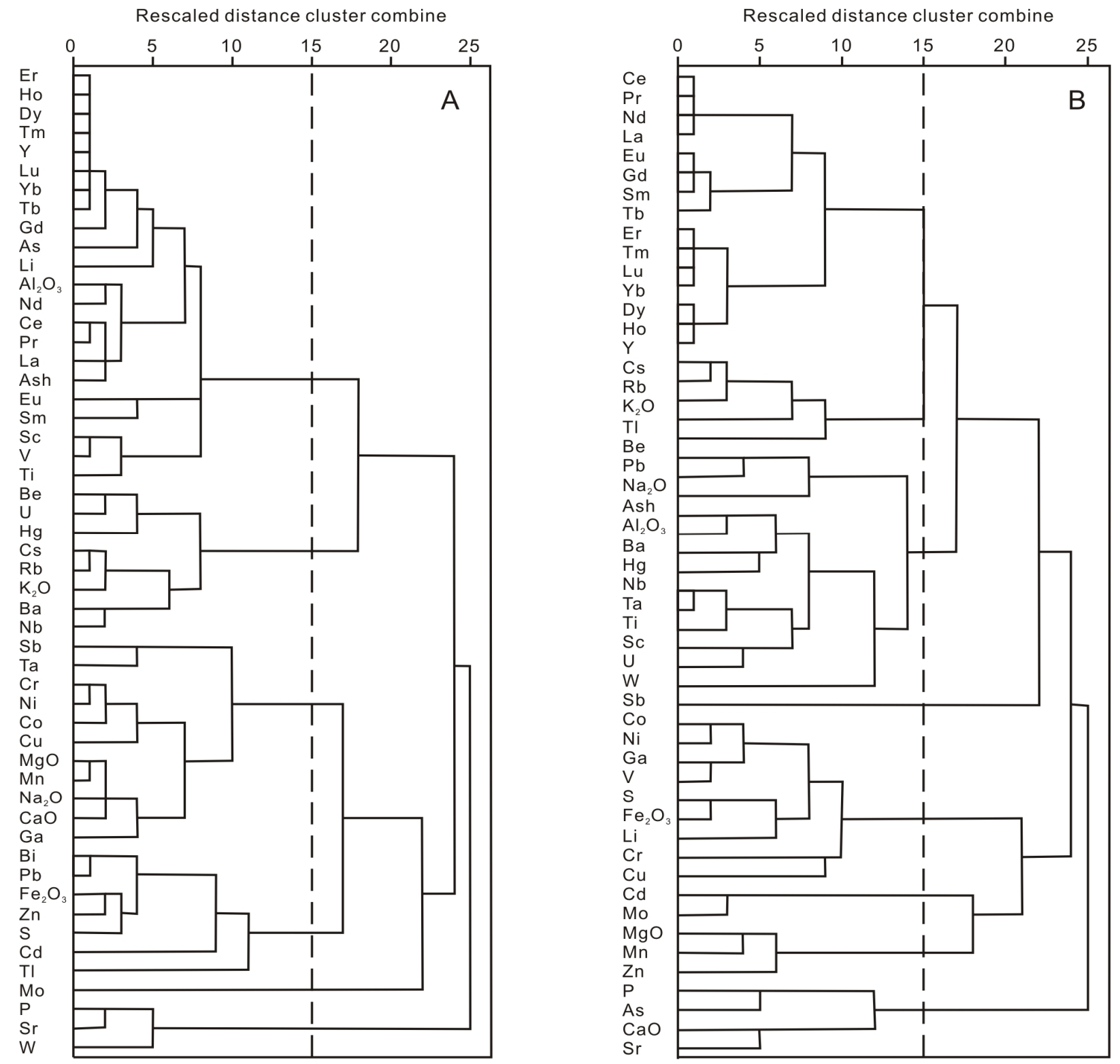

Fig. 2. Dendrogram produced by hierarchical cluster analysis of elemental concentrations from the Carboniferous (A) and Permian (B) coals in the Zhengzhuang area, Qinshui Basin, North China.

The first group consists of Er, Ho, Dy, Tm, etc. (Fig. 2). The correlation coefficients of Ce-Pr (1.00), La-Nd (0.98), Ti-Zr (0.98), Sc-Th (0.98), Er-Tm (0.98), Lu-Yb (0.96), Eu-Gd (0.99) and $\mathrm{Ga}-\mathrm{Nb}(0.99)$ are all higher than 0.95. Rare earth elements and A12O3 from this group have relatively high positive correlation coefficients with ash yield, and the best correlation was found between $\operatorname{Pr}$ and Ash (Fig. 5A, r=0.95). On a higher level of similarity this group may be subdivided into four subgroups: Group 1A, 1B, 1C and 1D (Fig. 2).

The second group consists of $\mathrm{Be}, \mathrm{U}, \mathrm{Hg}, \mathrm{Cs}, \mathrm{Rb}, \mathrm{K}_{2} \mathrm{O}, \mathrm{Ba}$ and $\mathrm{Nb}$ (Fig. 2), characterized by relatively high correlation coefficients $(\mathrm{r}=0.47-0.98)$ with each other. The best correlation in this group was found between $\mathrm{Cs}$ and $\mathrm{Rb}$ (Fig. 5B, r=0.98). On a higher level of similarity this group may be subdivided into two subgroups (Be, $\mathrm{U}, \mathrm{Hg}$, etc.). 
The third group consists of $\mathrm{Sb}, \mathrm{Ta}, \mathrm{Cr}, \mathrm{Ni}$, etc. The correlation coefficients between those elements range from 0.32 to 0.98 . On a higher level of similarity this group may be subdivided into two subgroups (Fig. 2).

The elements in Group 4 also can be divided into three subgroups: Group 4A, 4B and 4C (Fig. 2). $\mathrm{Bi}, \mathrm{Pb}, \mathrm{Fe} 2 \mathrm{O} 3, \mathrm{Zn}$ and $\mathrm{S}$ are classified into Group 4A. $\mathrm{Cd}$ and $\mathrm{Tl}$ belong to Group 4B and 4C, respectively (Fig. 5C).

Group 5 is $\mathrm{P}-\mathrm{Sr}-\mathrm{W}$ association (Fig. 4). Their correlation coefficient is $\mathrm{P}-\mathrm{Sr}(\mathrm{r}=0.93), \mathrm{P}-\mathrm{W}$ $(\mathrm{r}=0.79)$ and $\mathrm{Sr}-\mathrm{W}(\mathrm{r}=0.87)$ (Fig. 5D).

Mo has low correlation coefficients with any of the above elements and is not included in these five associations (Fig. 4).

\section{Conclusions}

The arithmetic means of concentrations for most elements in the Carboniferous and Permian coal samples is present in the range of the world concentrations. The contents of $\mathrm{Ba}, \mathrm{Bi}, \mathrm{Cd}, \mathrm{Co}$ in the Carboniferous coals and $\mathrm{As}, \mathrm{Ba}, \mathrm{Bi}, \mathrm{Cd}$ in the Permian coals are lower than those of common Chinese coals. Compared with the Permian coals, the Carboniferous coals are enriched in $\mathrm{Ca}, \mathrm{Fe}, \mathrm{Mg}$ and $\mathrm{Cd}$, but the Permian coals are enriched in $\mathrm{P}, \mathrm{Ti}, \mathrm{Ba}$ and $\mathrm{Nb}$.

The elements in the coals may be classified into five associations by cluster analysis. The first group comprises elements with positive correlation with the ash yield. The elements from the remaining four associations have lower positive or negative correlation coefficients with ash yield.

\section{Acknowledgments}

We thank Wei Li and Han He for their assistance in lab work. We appreciate the critical comments of U. Brand and Qiang Li on the manuscript.

\section{References}

[1] S.F. Dai, D.X. Han, C.L. Chou: submitted to China Fuel (2006)

[2] S.F. Dai, D.H. Li, D.Y. Ren, Y.G. Tang: submitted to Appl. Geochem. (2004)

[3] S.F. Dai, D.Y. Ren, C.L. Chou, R.B. Finkelman, V.V. Seredin: submitted to Int. J. Coal Geol. (2012)

[4] X. Querol, A. Alastuey, A. LopezSoler, F. Plana, J.L. Fernandez Turiel, R.S. Zeng: submitted to Int. J. Coal Geol. (1997)

[5] X.B. Su, X.Y. Lin, M.J. Zhao, Y. Song, S.B. Liu: submitted to AAPG Bulletin. (2005)

[6] D.J. Swaine: Trace Elements in Coal. (Butterworth Publications, London 1990)

[7] L. Wei, Z.H. Zhi, Y.C. Yong, S.H. Minghua: submitted to J. Geochem. Explor. (2006)

[8] J.Y. Zhao, X.Y. Tang, W.H. Huang: submitted to Coal Geology of China (2002)

[9] X.G. Zhuang, X. Querol, A. Alastuey, F. Plana, N. Moreno: submitted to Int. J. Coal Geol. (2007)

[10] X.G. Zhuang, S.C. Su, M.G. Xiao, J. Li, A. Alstuey, X. Querol: submitted to Int. J. Coal Geol. (2012) 